\title{
AN INTEGRATED METHODOLOGY FOR LAYOUT DESIGN AND WORK ORGANISATION IN A FURNITURE MANUFACTURING PLANT
}

\author{
A. Sutcu ${ }^{1, *}$, E. Tanritanir ${ }^{2}$, B. Durmusoglu ${ }^{3}$ and H.I. Koruca ${ }^{4}$ \\ ${ }^{1,2}$ Department of Forest Products Engineering \\ Suleyman Demirel University, Turkey \\ asutcu@orman,sdu.edu.tr, ettanir@istanbul.edu.tr \\ ${ }^{3,4}$ Department of Industrial Engineering \\ Istanbul Technical University, Turkey \\ durmusogl1@itu.edu.tr, koruca@mmf.sdu.edu.tr
}

\begin{abstract}
This study aims to provide an integrated methodology for re-designing the layout and departmental organisation in a job shop environment. While several studies have discussed the specific re-design or re-organisation of small- and medium-sized enterprises (SMEs) through simulation or mathematical models performing improvements, an integrated approach is rare. An integrated simulation-based methodology has been developed for simultaneously re-designing the layout and the departmental organisation of an SME manufacturing facility. A wooden chair manufacturing facility has been used as a case study. It is found that the developed methodology might be useful for other SME manufacturing firms, especially in the furniture industry.
\end{abstract}

\section{OPSOMMING}

Hierdie studie hou ' $n$ geïntegreerde metodologie vir die herontwerp van uitleg en departementele rangskikking in ' $n$ stukwerkwinkel voor. Terwyl verskeie studies die spesifieke herontwerp en herrangskikking van klein- en mediumgrootte ondernemings deur simulasie en wiskundige modelle probeer verbeter, is ' $n$ geïntegreerde benadering raar. ' $n$ Geïntegreerde simulasie-gebaseerde metodologie is ontwikkel en ' $n$ vervaardigingsaanleg wat houtstoele produseer word as gevallestudie voorgehou. Die toepassing van die model word as nuttig beskou vir ander klein- tot mediumgrootte ondernemings in die meubelbedryf.

\footnotetext{
${ }^{1}$ The author was enrolled for a PhD degree in the Department of Business Administration, Suleyman Demirel University.

${ }^{*}$ Corresponding Author.
} 


\section{INTRODUCTION}

New information technologies, which encourage the globalisation of markets and cause important shifts of market 'power' to consumers, also have dramatic potential to serve furniture manufacturing and marketing (Bullard \& West [1]).

Increasing competition - along with rapid changes in consumer demand - lead manufacturers to redesign their facilities and other organisational structures to satisfy the needs of different product groups and styles. A number of advanced manufacturing systems and organisational paradigms - such as lean manufacturing, agile manufacturing, and decentralised and autonomous production cells - have emerged in recent years to improve efficiency. Nevertheless, one of the key issues for organising manufacturing is to select the approach that will meet the needs best and most appropriately. Another key issue is managing the reorganisation appropriately.

Redesigning facilities in furniture manufacturing is affected by the following characteristics: (1) there is usually a wide assortment of products, (2) lot size tends to be small, (3) the life-span of most designs is short (furniture, like clothing, is a fashion), (4) there is a wide variety of raw materials (solid wood, plastics, metals, upholstery, and many wood-based semi-manufactured products) (Paavola [2]). In such environments, machines must be able to perform a variety of production operations on a variety of materials. The design of a parts manufacturing workshop can be classified into two basic layout types. While functional departments are composed of machines with similar capabilities that perform similar functions, in cellular manufacturing (CM) individual resources are aggregated into manufacturing cells, each dedicated to manufacture one or more part families. In other words, cell formation combines machines of different technologies so that all parts of a certain family are grouped together. Some benefits of CM include reduced setup time for processing similar parts, increased throughput, decreased lead times, improved productivity and materials handling, and reduced work-in-process (WIP) inventories. At present most large Japanese companies, such as Sony, Panasonic, Canon, NEC, Fujitsu, Hitachi, and others, have adopted CM; and most of them have obtained great benefits. In Japan, CM is the most popular innovation (Kaku et al. [3]).

However, Shafer \& Meredith [4] have shown that functional layout can achieve better performance in certain cases. In particular, several simulation studies have shown that, in certain circumstances, the use of functional layout can achieve good performance. Indeed, as noted by Harhalakis et al. [5], the features of many workshops are not appropriate for purely cellular manufacturing, since batch sizes become progressively smaller and the product variety increases, as stated above. Consequently, parts within each family become less similar. On the other hand, a purely functional organisation can lead, depending on the type of the workshop, to great disorder in the flow of parts, and thus perform poorly.

In the furniture manufacturing industry, by applying a revised algorithm of King [6] in a panel plant, Kumar \& Motwani [7] and Tanritanir [8] made cellular manufacturing suitable for large scale applications. Their cost and benefit analysis provided important benefits, including significant reductions in material movement, set-up times, work-in-process (WIP), work space, and a remarkable improvement in employees' team spirit. However, according to a study by Acuna [9] in a chair manufacturing facility, differences between a process design for the machining room based on a cellular layout and one based on a functional layout were not significantly important.

As an alternative to these two systems, hybrid systems combine manufacturing cells as usually defined in the group technology (GT) literature and functional cells, i.e. cells composed of machines of identical technologies (Viguier \& Pierreval [10]). Gravel et al. [11] propose forming GT-cells in a functional shop in the particular case where the majority of products require almost all of the different types of equipment. Shambu \& Suresh [12] also observed that hybrid shops are frequently encountered in the real word, and studied the performances of hybrid CM systems using simulation. Viguier \& Pierreval [10] suggested a 
constrained multi-criteria approach, which favoured cells for the parts that were regularly manufactured over time and that contributed significantly to the flow of parts in the workshop. They proposed an evolutionary programming algorithm and illustrated it on a test example.

In addition to the layout design, human aspects need to be considered to create new work systems with high productivity and flexibility. To give participants the possibility of experiencing different effects, new forms of organisational structures, new forms of work organisation, and new principles of work structuring, the systematic planning of work structures is supported by a guideline that includes planning of variants. The design and evaluation of the departmental organisation of a mechanical engineering enterprise with simulation is the focus of Zülch \& Brinkmeier [13] and Zülch et al. [14]. In addition, Rahimifard \& Weston [15] outline how a particular choice of well-proved enterprise and simulation modelling techniques can be used in an integrated fashion while describing interim research findings when using such an integrated modelling approach in a case study from the furniture manufacturing industry.

Usually studies on furniture manufacturing industries do not sufficiently focus on developing hierarchical and systematic roadmaps to redesign both workshop layout and departmental organisation. However, the furniture manufacturing industry is driven by increased competition, sophisticated customer demands, rapid advances in technology, and flexibility towards different types and quantities of products. It is necessary to define methodologies for manufacturing that are capable of identifying the driving forces of change and coping with the resultant changes. Therefore, this study aims to describe a road map for the redesign and re-structuring of an existing manufacturing system. For this purpose, a chair manufacturing firm has been examined with this methodology, and performance values have been obtained.

The paper is organised as follows: Section 2 describes the methodology. Implementation of the methodology in a chair manufacturing workshop is given in Section 3. Conclusions and suggestions for further research are given in Section 4.

\section{METHODOLOGY}

\subsection{Road map for redesigning a workshop}

Simulation is a useful tool for the analysis of complex systems. Shannon [16] defines simulation as the process of designing a model of a real system and conducting experiments with the model for the purpose of understanding the behaviour of the system and/or evaluating various strategies for the operation of the system. In this study, a user-friendly road map that uses simulation, considers different scenarios, and allows manual applications where the decision-maker has complete control, has been developed to redesign workshops.

Figure 1 shows the algorithm of the methodology. In the section represented by (A1), a simulation model of the existing system is developed to assess the initial performance of the system. After evaluating the existing system performance, the decision-maker can determine either a departmental re-organisation or a layout redesign. If a layout redesign is required, then process $(\mathrm{A} 2)$ will start. At this stage, the decision-maker prefers a cellular, functional, or hybrid layout system. While the functional layout has some advantages (usually such as high machine utilisation at work centres and high flexibility in allocating operations to alternative machines in any work centre), the disadvantages of the functional layout include high throughput times, high WIP levels, complex order tracking and production control, as well as frequent and sometimes long set-ups. The advantages of a cellular layout include low lead times and low WIP levels. However, high machine utilisation is not guaranteed in all cells unless demand for the parts they produce is high and stable enough to achieve the desired utilisation of cell resources. 


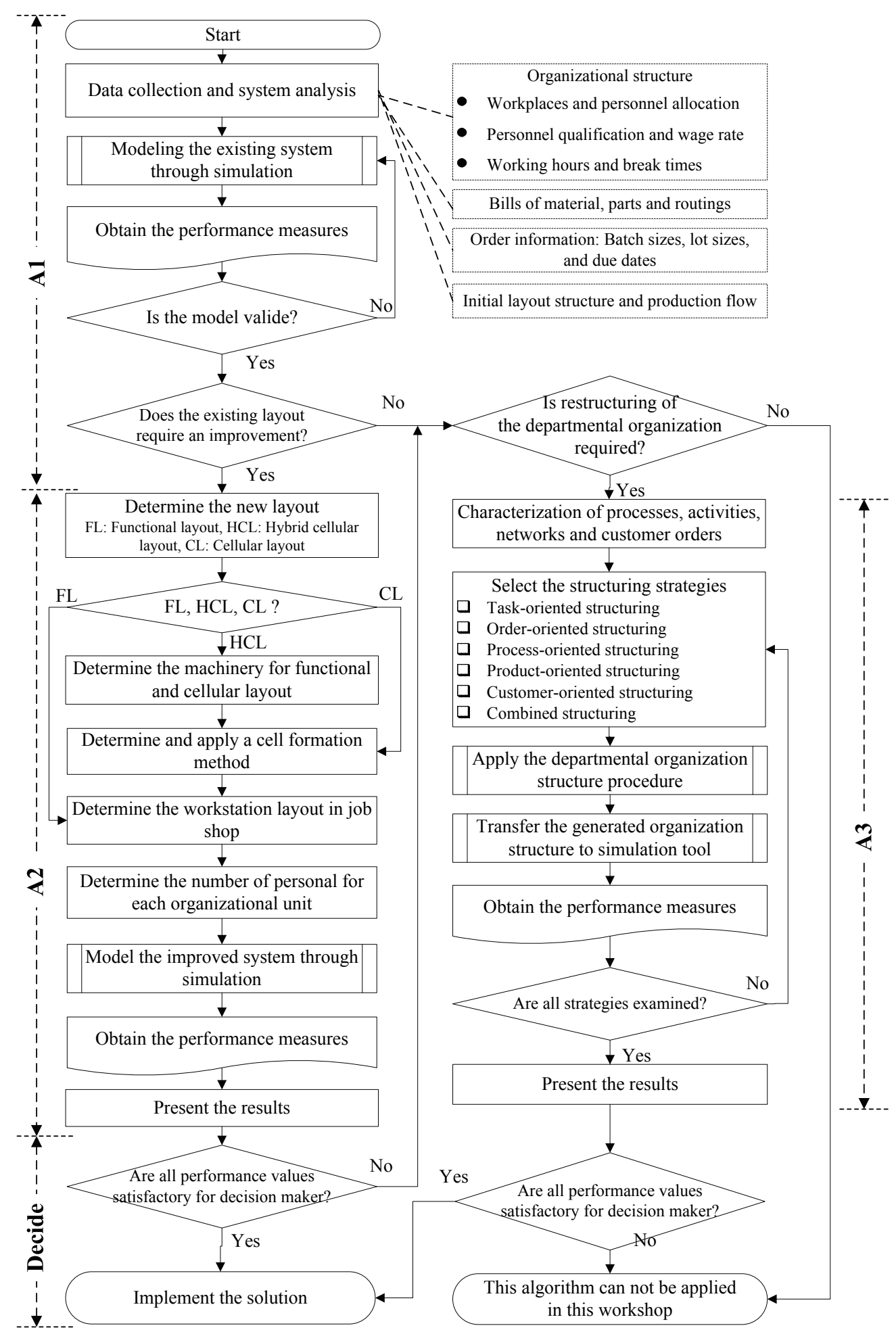

Figure 1: An integrated methodology for re-design of a furniture manufacturing workshop 
Also, in case of machine breakdowns and changes in demand or product mix, a cell designed to produce a single part family in a certain quantity range tends to be inflexible and unsuitable for reconfiguration (Fig. 2).

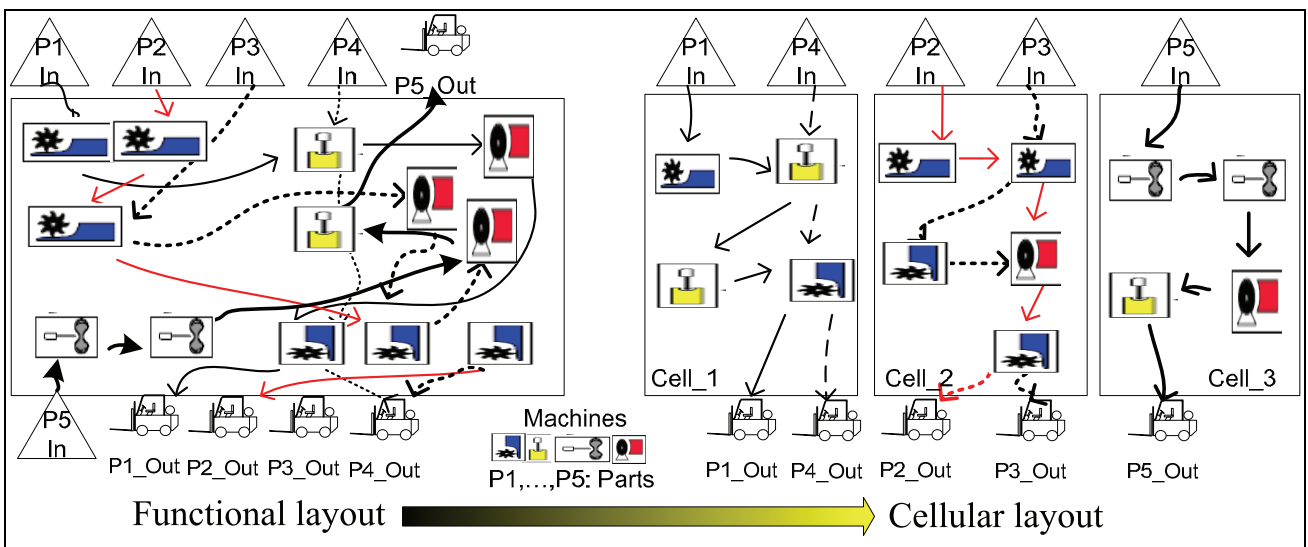

Figure 2: Functional layout and cellular layout

The hybrid cellular layout integrates the attributes of both functional and cellular layouts. Rather than utilising a cellular or functional layout for a job shop, hybrid cellular layout provides a novel fusion of partial conversion to a cellular layout, functional grouping of several shared machine types, limited physical duplication of shared machines, and intercell flows (Irani \& Huang [17]).

Herhalakis et al. [5] offer the following conclusions about the development and application of the hybrid cellular layout:

- A pure cellular arrangement is not practical in a typical industrial environment.

- The problem of hybrid facility design can conveniently be decomposed into a sequence of sub-problems, e.g. cell formation and evaluation cell layout and shop layout.

- $\quad$ These sub-problems may be solved more than once to arrive at a good solution.

- It is necessary to consider a consistent objective for all stages of the facility design problem.

- $\quad$ Practical issues, such as similarities in set-ups and changes in production mix, should be considered if the final solution is to have practical significance.

In section $\mathrm{A} 2$, if the performance values of improved structure are satisfactory compared with the performance values of the current structure, the new layout is proposed to the decision-maker for application. Otherwise, section A3 is carried out.

In section A3, departmental organisation is proposed. For this purpose, a detailed characterisation of the relevant processes and operations is necessary. After that, different structuring strategies will be used during the restructuring process in order to define organisational prototypes based on the process characteristics.

In the last stage, the decision-maker evaluates the improved system performance and decides whether or not to implement the related model. If any one of the examined strategies is not satisfactory, or if the original structure does not need improvement, then the algorithm cannot be applied in the workshop. 


\subsection{Modelling of the existing system and analysis through simulation - A1}

In $\mathrm{A} 1$, a simulation model of the existing system is designed to improve performance. Depending on the nature of the study, a simulation model requires precisely defined relationships between the collected data and the system elements. Even if the model is developed perfectly, a practitioner cannot expect to obtain accurate output data unless the model uses accurate input data (Chung [18]). Although Chung [18] asserts that typically too little time is allocated for this process, the data collection stage is considered as the most difficult part of the simulation process. Thus the author concludes that the problem is aggravated by the fact that many practitioners probably prefer to develop a simulation model rather than collect mundane data. The necessary data for simulation are: number and qualifications of personnel, hourly personnel payments, work and break times, processing and set-up times for personnel, numbers of machines and benches, work functions, processing and set-up times for machines, transfer times between machinery, maintenance and breakdown times and their distributions, fixed and variable costs, product programme, part routes, and order and lot sizes. System load is determined by considering the starting time for manufacturing the ordered products, due dates, and order sizes.

After gathering and evaluating the input data, the existing system is modelled with an appropriate simulation tool. Subsequently a validation process should be executed. Validation is the process of reaching an acceptable level of confidence that the inferences drawn are correct and applicable to the real-world system as represented. Sargent [19] describes various validation techniques (and tests) used in simulation model validation. These techniques can be used either subjectively or objectively. The term 'objectively' is defined as using some statistical test or mathematical procedure (e.g., hypothesis tests and confidence intervals). A combination of techniques can also be used.

In evaluating the effects of the different variations, the following performance metrics have been utilised: Goal achievement for lead time degree, goal achievement for utilisation, goal achievement for work in progress, service ability, and personnel cost. Degrees of goal achievement relate the performance of a system to a theoretically optimal performance. If the optimal performance is achieved, the value of the degree of goal achievement will be $100 \%$. The definitions of these performance metrics are given in Zülch et al. [20] in detail.

\subsection{Determining new layout - A2}

The detailed formulation of a real reorganisation problem is not universal. In other words, companies have organisational differences in terms of their products, services, processes, and so on. Even in the same sector or sub-sectors, it is difficult to fit the same structure to all companies. To determine the best structure, organisationally-oriented analyses should be used. In this study, a hybrid CM system structure is preferred as the ideal structure for chair manufacturing workshops. A hybrid CM system allows both a functional layout and a cellular layout to co-exist. In a chair manufacturing process, some machines must be grouped together, based on functionality. For example, machines such as sanders must be together in a dust-free area. In addition, since the investment costs of some machines used by different departments are very high, it is not advisable to assign one machine to each cell, as machines in each cell may only process the parts in that cell in a pure cellular workshop.

To develop the hybrid $C M$ model, the parts that have the same routing first have to be grouped as one part family. Then the binary $\left[a_{i j}\right]$ part-machine incidence (PMI) matrix is created to show which part is processed by which machine. Each element $a_{i j}$ in the binary PMI matrix can have one of the following values:

$$
a_{i j}= \begin{cases}1 & \text { If part } j \text { requires an operation on machine } i \\ 0 & \text { Otherwise }\end{cases}
$$


In this PMI matrix, the machines which must be in a functional layout are grouped in the layout for reasons described earlier.

Cell formation decision for the rest of the machines is left to the decision-maker's preferred cell formation method. For this purpose, different decision support tools can be used, such as Vitanov et al. [21]. Operation sequences based cell formation methods are given by Sarker \& Xu [22]. If more than one method is applicable, then Grouping Efficiency can be used to evaluate the obtained solution matrices to achieve the best alternative (Chandrasekharan \& Rajagopalan [23]).

In this study, the similarity coefficient method based approach developed by Yasuda \& Yin [24] to solve the cell formation and Average Voids Value (AVV) has been used to create part-machine groups. The method developed by Aneke \& Carrie [25] has been utilised for the inter-cell machine layout decisions. After evaluating the findings of both heuristic methods mentioned above, a hybrid CM model similar to the layouts module of Irani \& Huang [17] has been created. It is assumed that the personnel in the modules are capable of using all the machines inside the module, and that they are responsible for all the machines.

\subsection{Determining the departmental organisation structure - A3}

Reorganisation measures in manufacturing received increasing attention in the last two decades of the last century. Manufacturing segmentation is one of the reorganisation measures that gained particular importance for parts manufacturing, and has been a configuration paradigm for at least two decades. It is important to examine critically which type of segmentation is meant in a certain application case, and which of the different possibilities would be most suitable for this case. A critical analysis has been conducted by Zülch \& Brinkmeier [13], who present a procedure that builds on the classification of the work operations within the manufacturing area, and thereby considers the relationship between the work operation and a certain order type, an individual customer or a customer group, the type of product, and the type and scope of the elementary process contained in the work operation. This approach can generally be applied beyond the area of parts manufacturing and assembly to all production-related function areas.

Zülch \& Brinkmeier [13] provide various structuring principles for the assignment of work operations to organisational units - that is, departments, segments, work groups, and sites whereby one can differentiate between function-, process-, product-, order-, and customer-orientation. While the first two strategies focus on the enterprise-internal organisational structure (endogenous strategy-orientation), the last two are orientated toward criteria from the sales market (exogenous strategy-orientation). The manufacturing segmentation is often carried out according to the principle of product-orientation, which considers both dimensions to a certain degree. The problem is that this structuring strategy is not always best suited to a given application case, and one of the other forms may sometimes be better suited. The application of simulation technology, however, can contribute greatly to the solution of this problem.

For re-organising the departmental units, a detailed characterisation of the relevant processes and operations is needed. In the procedure presented by Zülch \& Brinkmeier [13], specific features have been defined for the essential process requirements of the manufacturing processes: type of output, type of customer, type of task, complexity of task, type of order, and product structure. Figure 3 shows the set of basic characteristics of chair manufacturing processes. Based on these characteristics, the activities are classified, and each activity in a process network can be described by a set of attributes. These attributes are either related to the activity itself or related to the specific process network to which it belongs. 


\begin{tabular}{|c|c|c|c|c|c|c|c|c|c|}
\hline Strategies & Characteristics & \multicolumn{7}{|c|}{ Attributes } & Linkage \\
\hline $\begin{array}{l}\text { Process } \\
\text { oriented }\end{array}$ & $\begin{array}{l}\text { Type of } \\
\text { output }\end{array}$ & Post & \multicolumn{2}{|c|}{ Back } & Stretcl & & \multicolumn{2}{|c|}{ Assembled parts } & \\
\hline \multirow[b]{2}{*}{$\begin{array}{l}\text { Product } \\
\text { oriented }\end{array}$} & \multirow{2}{*}{$\begin{array}{l}\text { Product } \\
\text { structure }\end{array}$} & \multicolumn{3}{|c|}{ Simple structure } & \multicolumn{4}{|c|}{ Complex structure } & \\
\hline & & Few parts & \multicolumn{2}{|c|}{$\begin{array}{c}\text { Multiple } \\
\text { components }\end{array}$} & \multicolumn{3}{|c|}{ Few parts } & $\begin{array}{c}\text { Multiple } \\
\text { components }\end{array}$ & \\
\hline $\begin{array}{l}\text { Order } \\
\text { oriented }\end{array}$ & Type of order & \multicolumn{2}{|c|}{ New order } & \multicolumn{2}{|c|}{ Variant order } & \multicolumn{3}{|c|}{ Repeat order } & \\
\hline \multirow{2}{*}{$\begin{array}{l}\text { Customer } \\
\text { oriented }\end{array}$} & \multirow{2}{*}{$\begin{array}{l}\text { Type of } \\
\text { customer }\end{array}$} & \multicolumn{4}{|c|}{ Customer reference } & \multicolumn{3}{|c|}{ Firm reference } & Order \\
\hline & & Domestic ma & & Global m & arket & & wroom & Retailer & \\
\hline \multirow{2}{*}{$\begin{array}{c}\text { Task } \\
\text { oriented }\end{array}$} & Type of task & Handling & & Machir & ing & & sembly & Inspection & \multirow[b]{2}{*}{ Activity } \\
\hline & $\begin{array}{c}\text { Complexity of } \\
\text { task }\end{array}$ & \multicolumn{2}{|c|}{ Highly complex } & \multicolumn{2}{|c|}{ Complex } & \multicolumn{2}{|c|}{ Diffucult } & Simple & \\
\hline
\end{tabular}

Figure 3: Basic features for the characterisation of chair manufacturing processes

Product-oriented, customer-oriented, process-oriented, task-oriented, and order-oriented structuring strategies have been identified as suitable for an efficient and effective production process (see Zülch et al. [14]; Zülch \& Brinkmeier [13]). However, their usefulness for a specific case must be checked before application - that is, by simulation.

In the Product-oriented structuring strategy (Product OS), personnel are assigned to a manufacturing process according to the different types of products or product groups, with the aim of achieving synergy and training effects. As a result, reduced times for set-ups and reduced process times can be obtained, due to repeated execution (see Figure 3).

Customer-oriented structuring strategy (Customer OS) aims to align the organisation towards manufacturing of a product according to the demands of a special customer or customer type. The major benefit of this strategy is reduced reaction times to their demands, with a higher customer satisfaction level (see Figure 3).

The intent of the Process-oriented structuring strategy (Process OS) is to optimise the order flow through structuring according to the production procedures (see Figure 3 ).

The Task-oriented structuring strategy (Task OS) has the goal of focusing on technical competence and human-related productivity by combining similar tasks or functions into the same departmental unit. The repetition of similar tasks may allow for a certain specialisation of the assigned personnel, and may lead to reduced process times (see Figure $3)$.

The Order-oriented structuring strategy (Order OS) combines similar production orders, such as customer orders, restocking, or spare parts orders, into separate departments. Assigning order-specific activities to specialised personnel may increase human productivity while holding the range of assigned activities at a higher level (see Figure 3).

\section{CASE STUDY}

\subsection{Manufacturing procedure}

The following study is carried out using the data collected in a chair manufacturing workshop of Boytas Furniture Industry and Trade Inc. The daily capacity of the workshop, where make-to-order (MTO) type production is used, is 1500 wooden chairs (Boytaș [26]). As seen in Figure 4, the existing layout of machinery and workstations is functional. 


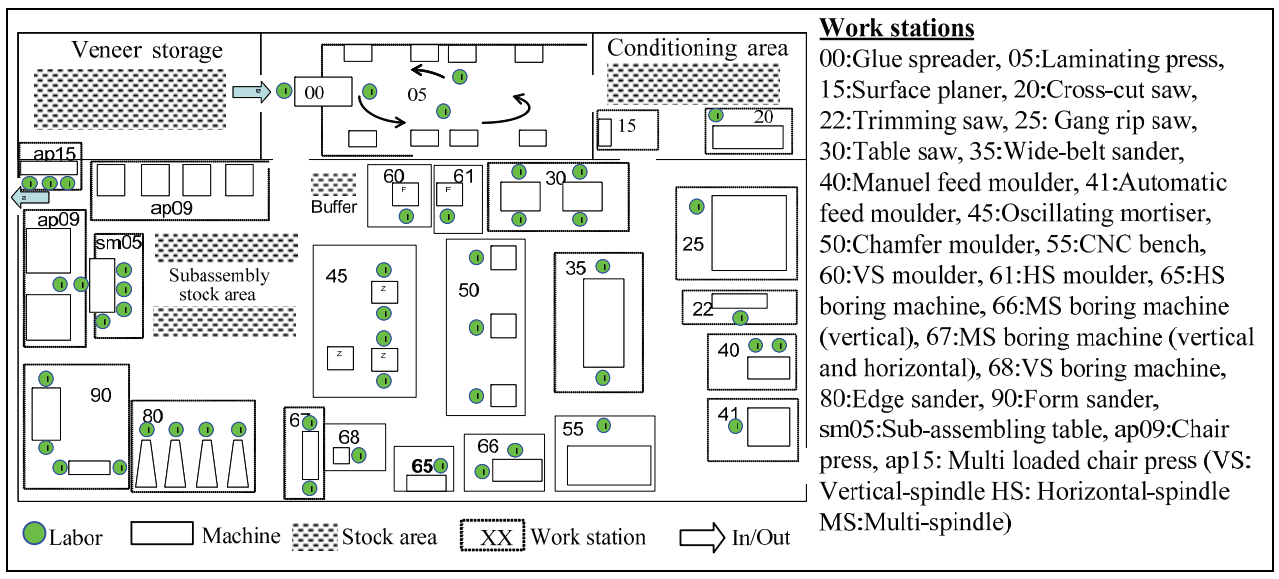

Figure 4: Initial layout of the chair manufacturing workshop

Laminated materials, which are produced by pressing beech veneer and lathed woods, are used as raw materials. Pressed boards are converted into individual parts by using a gang rip saw. Then all parts are moved through the other work stations as lots for the operations. The parts that require sub-assembly are pre-assembled at an assembly table or a chair press, depending on the properties of the products. Seats that come from the upholstery shop, and massive or laminated wood parts that are surface-finished in the polishing shop, are put together in a packing unit. The final assembly of the pre-assembled chair parts takes place at the final destination - the consumer's home.

\subsection{Modelling and analysis of initial situation}

Operation and set-up times were established as deterministic values of 393 operations in 4 product groups (chair types). Personnel work 9 hours a day and 45 hours a week. Parts are transferred between the machines and the work station lots on manually operated forklifts. Therefore, the input of raw material parts and the output of the machines have to wait for transporters. The waiting times of the parts were found to be 10 minutes between the adjacent departmental units, and 30 minutes between the other departmental units, while the transfer time was only 15 seconds in the same departmental unit; for the conditioning, parts coming from the laminating press need to be cooled at least one day in the conditioning area. Order sizes for the model were randomly chosen by using uniform distribution U (200;300) (Figure 5). Other information and assumptions about the model are the following:

- The number of machines is fixed in all models.

- 45 workers are classified into three groups, based on their qualifications and wages.

- Working and break hours were considered in the model; overtime was not used.

- The FIFO rule was applied in production sequencing.

- The system worked at full performance capacity, and there was no idle time from break-downs or absence of personnel.

- There were no defective parts, and rework was not required.

- The simulation running time was one month $(2,592,000$ seconds).

After entering all data of the initial situation, a dynamic analysis of the modelled production structure was carried out using FEMOS. The simulation procedure FEMOS and the model generator GEMOS were both developed at the ifab-Institute of Human and Industrial Engineering (Prof. Gert Zülch) of the University of Karlsruhe (Germany). Further details are given by Zülch \& Brinkmeier [13]. 


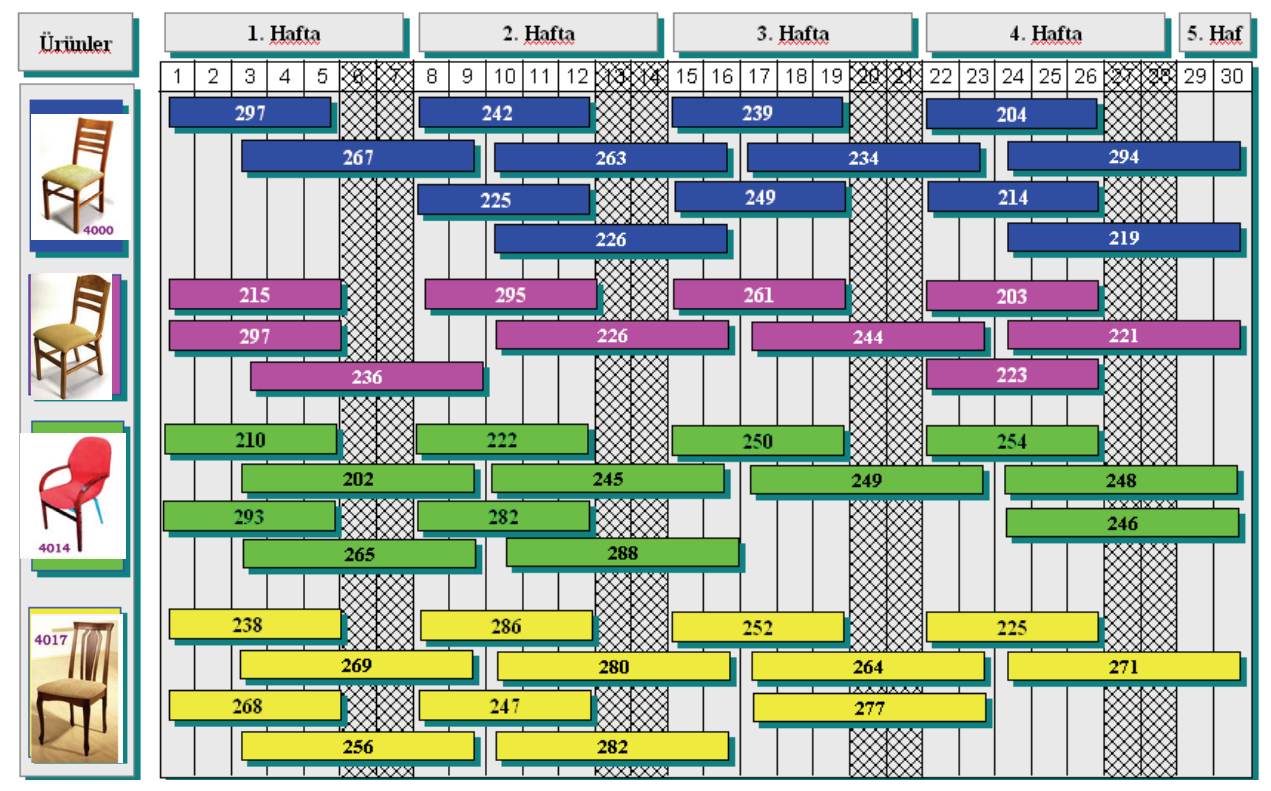

Figure 5: Order knowledge for any product type

FEMOS can be characterised as an organisation-oriented simulation tool. This program allows the differentiation between personnel and work places on the one hand, and the fusing of different work places to departments on the other hand. Also, sophisticated levels of capabilities of personnel can be modelled. Orders are described by function networks. In this way, parallel processing of different functions can be modelled easily (Zülch et al. [20]).

Model verification was performed by structured walkthroughs of model logic and extensive use of execution traces. During the modelling stage, FEMOS created the organisational structure and defined the relationship among the members of the system. FEMOS calculated the evaluation of the planning results in a 'before and after' situation, and the performance measurements. Model validation was done by the face validity method, which is normally achieved with the assistance of domain experts - an individual or group of individuals who are considered knowledgeable on the system under study (Chung [18]).

To evaluate the effects of the different variations, the following measurements have been used: Goal achievement for lead time degree, goal achievement for utilisation, goal achievement for work in progress, service ability, and personnel cost. Degrees of goal achievement relate the performance of a system to a theoretically optimal performance. If the optimal performance is achieved, the value of the degree of goal achievement will be $100 \%$. The definition of the logistical goal achievement has been given in detail by Zülch et al. [20]. The lead time degree of an order is the proportion of minimal possible lead time (i.e. the time-related capacity demand on the critical path of the order) and the lead time of the order calculated during the simulation run. Average lead time degree signifies the arithmetic mean of the lead time degrees of all completed orders. The performance values of the initial model are given in Table 1.

Goal achievement for

On-time delivery rate (Service ability) Quantity of personal Total personnel cost (\$)

$\begin{array}{lc}\text { lead time degree } & 4.87 \% \\ \text { utilisation } & 39.49 \% \\ \text { work in progress } & 4.07 \% \\ & 59.18 \% \\ & 45 \\ & 42,541.21\end{array}$

Table 1: Performance value of initial model 
Figure 6 gives a spaghetti diagram with very complicated routes, which was used to evaluate the product flow in the existing job shop. Complex order tracking and confusing material flows can be easily seen in this diagram.

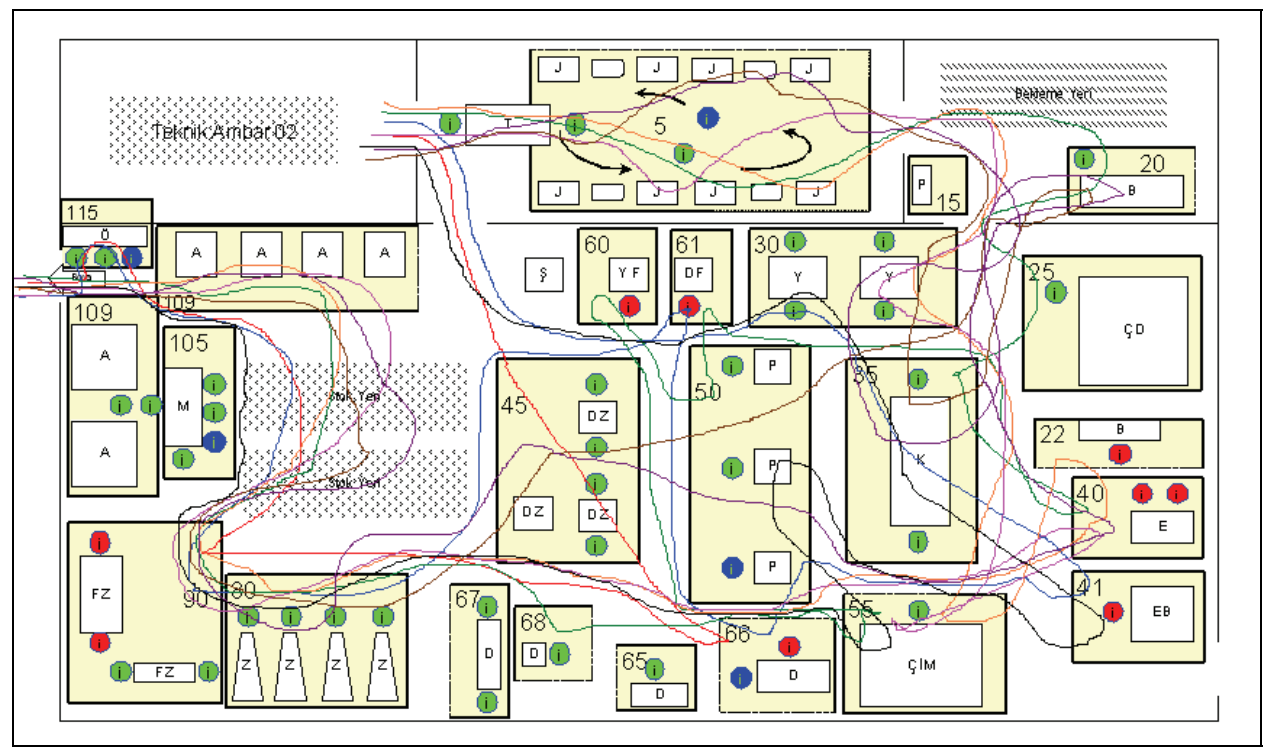

Figure 6: The spaghetti diagram for parts movement in the original workshop

After evaluating the system performance and the spaghetti diagram, and monitoring the online animation, it was decided to investigate layout re-organisation and departmental reorganisation to improve the existing system.

\subsection{Layout re-organisation}

To improve the performance of the existing system, a hybrid CM structure was initially designed. For this purpose, parts that follow the same route were grouped as one part. Then the binary PMI matrix was created to show which part is processed by which machine. Machines 05, 80, and 90 were kept for functional layout purposes for ergonomic reasons, while machine 35 was assigned for common use with other cell out ofsince its investment cost is high. The AVV method has been used to create part-machine groups for the remainder of the parts. Table 2 illustrates the cell formation results, which were generated by using cell loads and number of machines.

The method of Aneke \& Carrie [25] has been used for the layout of the machines in Cell_1. However, as Cell_2 consists of only three machines, the method was not required for this cell. Since the method constructs the flow line from both ends simultaneously, and this requires new investments such as new machinery, an ideal layout structure was obtained in Figure 7, allowing backtracking and repeated flows, as new machines are not necessary to supply the existing work load. For each departmental unit, the required number of personnel was determined by computing the work load and including an $8.4 \%$ idle-time allowance, as given in the literature (Oncer \& Asil [27]). 


\begin{tabular}{|c|c|c|c|c|c|c|c|c|c|c|c|c|c|c|c|c|c|c|c|c|c|c|c|}
\hline $\mathrm{n}$ & $\mathrm{m}$ & p 1 & p2 & $p 8$ & 015 & p4 & pil & $\mathrm{DOO}$ & pla & D13 & $P 5$ & PII & 18 & pli & p7 & 17 & p3 & pq & p6 & d12 & 114 & D21 & 016 \\
\hline 1 & 20 & 1 & 1 & 1 & - & 1 & 1 & 1 & 1 & - & - & - & - & - & - & 1 & - & - & - & - & - & - & - \\
\hline 3 & 45 & 1 & 1 & 1 & 1 & 1 & - & 1 & 1 & 1 & - & - & - & - & - & - & - & - & - & - & - & - & - \\
\hline 1 & 60 & - & - & - & - & 1 & 1 & 1 & - & 1 & - & - & - & - & - & 1 & - & - & - & - & - & - & - \\
\hline 1 & 25 & 1 & 1 & 1 & - & - & - & - & - & 1 & - & - & - & - & 1 & 1 & - & - & - & - & - & - & - \\
\hline 1 & 40 & - & 1 & - & - & 1 & 1 & - & 1 & - & 1 & 1 & 1 & 1 & - & 1 & - & - & - & - & - & - & - \\
\hline 1 & 22 & - & - & - & - & - & - & 5 & - & 1 & $-L$ & - & 1 & - & - & - & - & - & - & - & - & - & - \\
\hline 1 & 61 & - & - & - & - & - & $A$ & 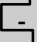 & ت & 1 & - & - & - & - & - & 1 & - & - & - & - & - & - & 1 \\
\hline 1 & 55 & - & - & - & - & & & & & & - & - & 1 & 1 & 1 & 1 & - & - & - & - & - & 1 & - \\
\hline 1 & 68 & - & - & - & - & - & - & - & - & - & - & - & - & - & 1 & 1 & - & - & - & - & - & - & - \\
\hline 1 & 66 & - & - & 1 & 1 & - & - & - & - & - & - & - & - & - & - & - & - & - & - & - & - & - & 1 \\
\hline 1 & 65 & 1 & - & - & - & 1 & 1 & - & - & 1 & - & - & - & - & - & - & - & 1 & 1 & 1 & 1 & - & - \\
\hline 2 & 50 & 1 & 1 & 1 & - & 1 & 1 & 1 & 1 & 1 & 1 & 1 & - & - & 1 & 1 & - & - & - & - & - & - & - \\
\hline 1 & 30 & - & - & - & - & 1 & 1 & 1 & 1 & - & 1 & 1 & 1 & 1 & 1 & - & - & - & $\sigma$ & 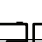 & П & O & - \\
\hline 1 & 41 & - & - & - & - & - & - & - & - & - & - & - & - & - & - & - & 1 & 1 & & 4 & 11 & T) & 1 \\
\hline 1 & 50 & - & - & - & - & - & - & - & - & - & - & - & - & - & - & - & 1 & 1 & 4 & 11 & & $\mathbb{1}^{<}$ & 1 \\
\hline 1 & 30 & - & - & - & - & - & - & - & - & - & - & - & - & - & - & - & 1 & 1 & 1 & 1 & 1 & 1 & 1 \\
\hline
\end{tabular}

Table 2: PMI matrix and cell formation

$\mathrm{n}$ : Quantity of machines $\mathrm{m}$ : Number of work station p1,...,p21: Parts family

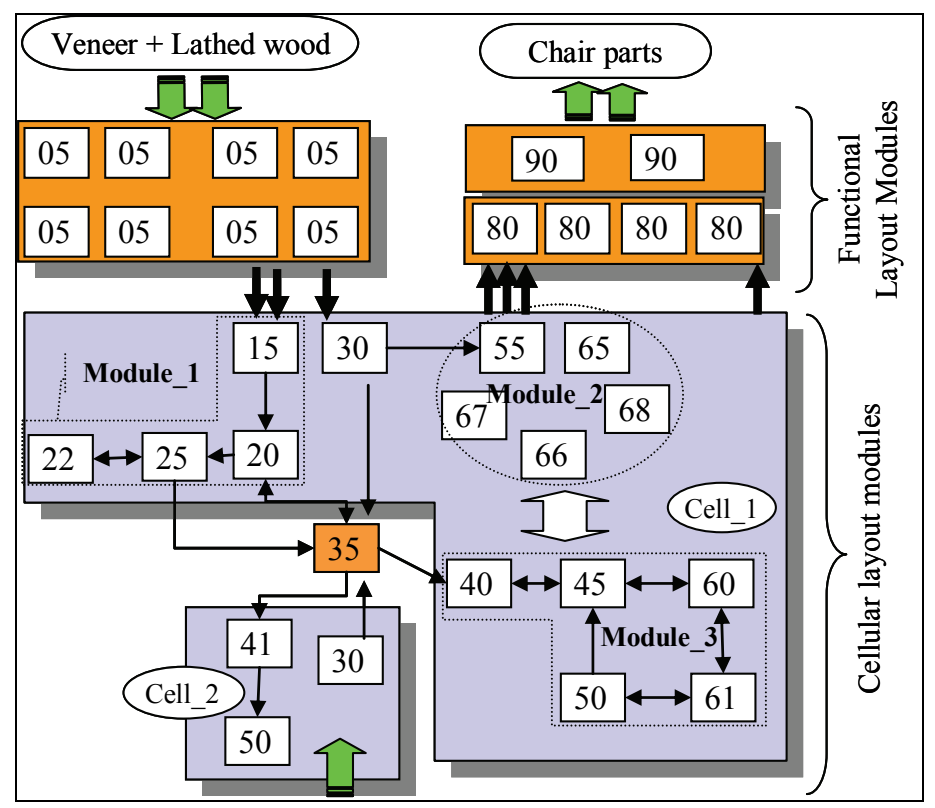

Figure 7: Hybrid CM layout for the workshop

\subsection{Departmental organisation}

The departmental organisation is based on detailed modelling and characterisation of the forecast order programme, especially on elementary processes or activities, activity networks, and production orders. The characteristics are used as a reference for the structuring strategies (see Figure 3). In the study, the segmentation approach was determined for the chair manufacturing workshop. 
For Product OS, product construction based classification has been made. The classification makes manufacturing products with few parts (easy tasks) as well as products with multiple components (complex jobs) possible in different departmental units.

For Customer OS, types of customer have been considered. Customer orders are initially grouped under either customer reference (which depends on the customer's requirements for the product) or firm reference (which entirely depends on overall demand). An additional classification has been made based on the market type (domestic or global) and the type of distribution channel (showroom or retailer). For Process OS, workflow for each part has been considered. For Task OS, type and complexity of task are considered for departmental organisation. Finally, for Order OS, the production order specification has been considered.

The organisation modelling tool FORM, which was developed by ifab, has been used to analyse the different forms of departmental organisation. Afterwards, an analysis of the created organisation has been carried out with the simulation tool FEMOS (Zülch \& Brinkmeier [13]).

\subsection{Simulation results}

To evaluate the effects of different forms of departmental organisation, the following parameters were measured: Goal achievements for lead time degree, utilisation and workin-progress, service ability, and personnel cost (Zülch et al. [20]).

In total, seven models, including the original situation, were generated and performance metrics recorded. The differences between simulated and initial system values are presented in Figure 8 . The values given in Figure 8 were obtained by subtracting reorganisation model performance values from the initial model performance values.

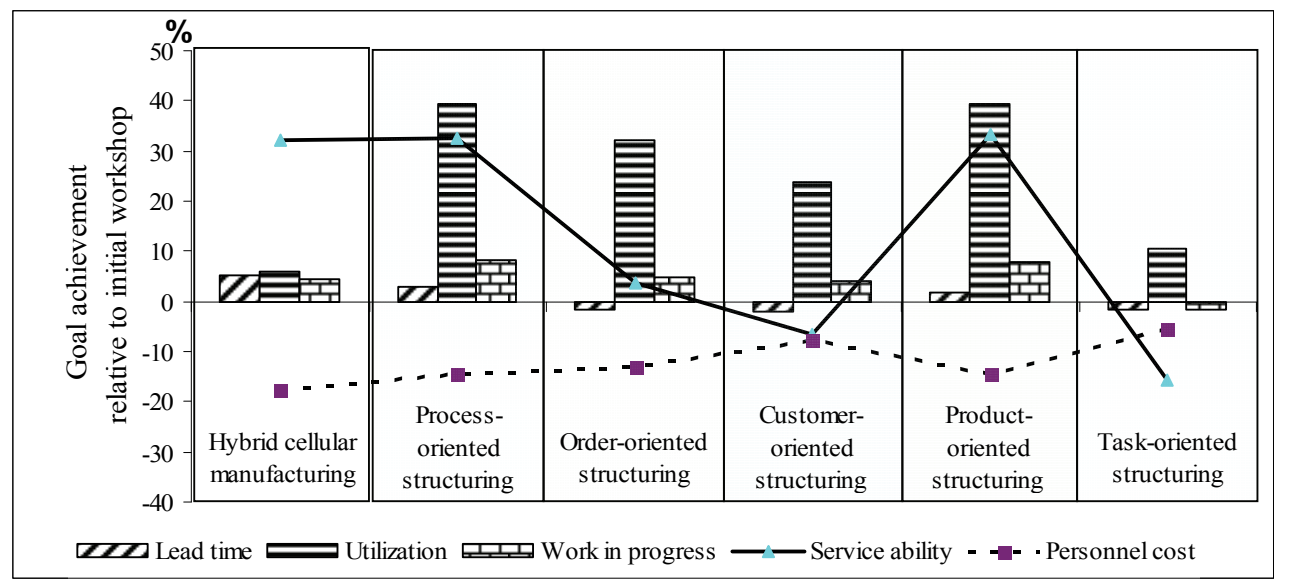

Figure 8: A comparative performance graph of simulated organisational structures

It was realised that the improvement in goal achievement for work in progress is low in all models. Possible reasons for that are discrete parts production, a high number of parts, long set-up times, and compulsory waiting times. However, in terms of total personnel cost, the models provide better results than the initial situation (Figure 8). Moreover, the lowest total personnel cost has been observed in hybrid $\mathrm{CM}$, in which a higher number of completed orders has been achieved.

The differences between the all models are summarised in Figure 8. Product OS shows the best performance values as a logistical goal. In particular, when the utilisation increased by 
about $40 \%$, goal achievement of work in progress also increased by about $8 \%$, with best ontime delivery performance at a reasonable personnel cost.

In hybrid $\mathrm{CM}$, the parts and machines were grouped, and so workflow was simplified within follow-up. It was revealed that grouping parts considerably improves on-time delivery success and logistical goals with a lower personnel cost.

It was also realised that, of all the models, Process OS had the highest success on work in progress and utilisation.

In Customer OS, Task OS, and Order OS, segmentations were made for better personnel productivity, job satisfaction, and customer satisfaction. However, any possible positive impact of these activities could not be totally revealed in the computer-based simulation models. Although the advantages of these models over the present situation could not easily be seen in Figure 8, performance improvements would be realised through reducing the number of customer complaints and improving personnel job satisfaction.

\section{CONCLUSION}

A roadmap to restructure an existing manufacturer is presented. Its practicability has been shown through simulation by structuring different scenarios. The results have shown that the most suitable structuring model depends on the company's preference objective, and thus on the business policy. The ideal structures for this firm have been the hybrid CM and Product OS to obtain shorter lead times, lower personnel costs, and a better on-time delivery; whereas Task OS has been chosen to obtain the best work performance.

The methodology developed in this study may be useful to other sub-furniture workshops, such as upholstery manufacturing, where it will help to attain an agile structure, since customer-driven designs are presently receiving more attention, while the lifecycle of products is diminishing in the sub-sector.

\section{ACKNOWLEDGEMENTS}

We are grateful to the SDÜ BAP for supporting this research under grant SDÜ-491. This work was undertaken in Boytaș Furniture Industry and Trade Inc., Turkey. We would like to thank the management and staff for allowing us free access to all the information used, and for their contribution to the project. Special thanks to Prof. Dr.-Ing. Dipl.-Wirtsch.-Ing. Gert Zülch, managing director of the ifab - Institute of Human and Industrial Engineering at the University of Karlsruhe, Germany.

\section{REFERENCES}

[1] Bullard, S.H. \& West, C.D. 2002. Furniture manufacturing and marketing: Eight strategic issues for the 21st century, Forest and Wildlife Research Center Bulletin FP 227, Mississippi State University.

[2] Paavola, P. 1989. Plant layout, in Furniture and joinery industries for developing countries, Vienna, UNIDO Publications.

[3] Kaku, I., Murase, Y. \& Yin, Y. 2008. A study on human-task-related performances in converting conveyor assembly line to cellular manufacturing, European Journal of Industrial Engineering, 2(1), 17-34.

[4] Shafer, S. \& Meredith, J.R. 1993. An empirically-based simulation study of functional operations overlapping, International Journal of Operations \& Production Management, 13(2), 47-62.

[5] Harhalakis, G., Lu, T., Minis, I. \& Nagi, R. 1996. Practical method for design of hybrid-type production facilities, International Journal of Production Research, 34(4), 897-918. 
[6] King, J.R., 1980. Machine-component grouping in production flow analysis: An approach using the rank order clustering algorithm, International Journal of Production Research, 18(2), 213-32.

[7] Kumar, A. \& Motwani, J. 1998. Case study: Reconfiguring a manufacturing system for strategic advantage - a real-world application, Logistics Information Management, 11(4), 244-256.

[8] Tanritanir, E. 1994. Cellular manufacturing system and its computer aided application in a furniture factory, I.Ü Orman Fakültesi Dergisi, A 44(2), 79-92.

[9] Acuna, J. 1996. Manufacturing simulation: A powerful tool for concurrent product and process design in chair manufacturing. PhD thesis, Purdue University, USA.

[10] Viguier, F. \& Pierreval, H. 2004. An approach to the design of a hybrid organization of workshops into functional layout and group technology cells, International Journal of Computer Integrated Manufacturing, 17(2), 108-116.

[11] Gravel, M., Price, W. \& Gagné, C. 2000. An interactive tool for designing manufacturing cells for an assembly job-shop, International Journal of Production Research, 38(2), 309-323.

[12] Shambu, G. \& Suresh, N.C. 2000. Performance of hybrid cellular manufacturing systems: A computer simulation investigation, European Journal of Production Research, 120(2), 436-458.

[13] Zülch, G. \& Brinkmeier, B. 2003. Prototyping the departmental organisation of an enterprise, International Journal of Production Economics, 83(2), 143-151.

[14] Zülch, G., Bogus, T., Koruca, H.I., Kurbanoglu, C. \& Brinkmeier, B. 2004. Simulation aided design of organizational structures in manufacturing systems using structuring strategies, Journal of Intelligent Manufacturing, 15(4), 431-437.

[15] Rahimifard A. \& Weston, R., 2007. The enhanced use of enterprise and simulation modelling techniques to support factory changeability, International Journal of Computer Integrated Manufacturing, 20(4), 307 - 328

[16] Shannon, R.E., 1998. Introduction to the art and science of simulation, In: D.J. Medeiros, E.F. Watson, J.S. Carson \& M.S. Manivannan (eds), Proceedings of the 1998 Winter Simulation Conference, Piscataway, NJ, IEEE.

[17] Irani, S.A. \& Huang, H. 2000. Custom design of facility layouts for multiproduct facilities using layout modules, IEEE Transactions on Robotics and Automation 16(3), 259-267.

[18] Chung C.A., 2004. Simulation modeling handbook: A practical approach, CRC Press, Boca Raton.

[19] Sargent, R.G., 2000. Verification, validation, and accreditation of simulation models, In: J.A. Joines, R.R. Barton, K. Kang \& P.A. Fishwick (eds), Proceedings of the 2000 Winter Simulation Conference. Piscataway, N J, IEEE, pp. 50-59.

[20] Zuilch, G., Grobel, T. \& Jonsson, U. 1995. Indicators for the evaluation of organizational performance, in Benchmarking - Theory and practice (ed. A. Rolstadas), London, Chapman \& Hall, 311-321.

[21] Vitanov, V., Tjahjono, B. \& Marghalany, I. 2007. A decision support tool to facilitate the design of cellular manufacturing layouts, Computers \& Industrial Engineering, 52 (2007), 380-403.

[22] Sarker B.R. \& Xu, Y. 1998. Operation sequences-based cell formation methods: A critical survey, Production Planning \& Control, 9(8), 771-783.

[23] Chandrasekharan, M.P. \& Rajagopalan, R., 1986. An ideal seed non-hierarchical clustering algorithm for cellular manufacturing, International Journal of Production Research, 24(2), 451-464.

[24] Yasuda, K. \& Yin, Y., 2001. A dissimilarity measure for solving the cell formation problem in cellular manufacturing, Computers \& Industrial Engineering, 39(1-2), 117.

[25] Aneke, N.A.G. \& Carrie, A.S., 1986. A design technique for the layout of multiproduct flowline, International Journal of Production Research, 24(3), 471-481.

[26] Boytaş, 2009. www.boytas.com.tr

[27] Öncer, M. \& Asil, N., 1992. Iss örneklemesi yöntemiyle dört modern mobilya fabrikasında kayıp zamanların saptanması ve önleme yolları (Turkish). Milli Prodüktivite Merkezi Yayınları, Turkey. 
